\title{
Hábitos imagéticos dos jovens: o auge dos stories e a inexpressividade das narrativas em 360 graus
}

\author{
Young people's images habits: the height of stories and the \\ inexpressiveness of 36o-degree narratives
}

Hábitos con imágenes de jóvenes: el apogeo de los stories y la inexpresividad de las narrativas de 360 grados

\author{
Alan César Belo ANGELUCI ${ }^{1}$ \\ Carolina Gois FALANDES ${ }^{2}$
}

\section{Resumo}

Contempla-se uma geração imagética, que tem no mundo on-line o principal suporte para a condução de suas práticas interacionais permeadas por visualidades. Protagonistas desse cenário midiático, os jovens se apropriam de variadas plataformas digitais para se educar, se informar, se entreter e trocar experiências entre os pares, mediados por múltiplas telas que transbordam conteúdos imagéticos. Com o objetivo de verificar de que maneira essa população consome e se relaciona com as imagens digitais e suas inovações, este estudo traz análises sobre um conjunto de dados quantitativos coletados por meio de um survey, respondido por 290 estudantes. Dentre os resultados, destaca-se o smartphone como principal dispositivo comunicacional, a preferência pela produção de fotos, o Instagram - sobretudo via stories - como a rede mais utilizada e a inexpressividade das narrativas em 360 graus nas rotinas juvenis.

Palavras-chave: Imagens Digitais; Redes Sociais Virtuais; Jovens; Stories; Imagens em 360 Graus.

\footnotetext{
${ }^{1}$ Professor permanente no PPGCOM (Linha de Pesquisa Produção e Recepção da Informação Pública), PPGE (Linha de Pesquisa Formação docente e profissionalidade) e na Graduação em Comunicação Social (Escola da Indústria Criativa) na Universidade Municipal de São Caetano do Sul (USCS). Líder do grupo de pesquisa Smart Media \& Users (SMU - CNPq). E-mail: aangeluci@gmail.com. ORCID: 0000-0002-4093-0590.

${ }^{2}$ Doutoranda em Comunicação pela Faculdade de Arquitetura, Artes, Comunicação e Design da Universidade Estadual Paulista (UNESP). Participante do Grupo de Estudos sobre Nova Ecologia dos Meios (GENEM - CNPq) e pesquisadora do Smart Media \& Users (SMU - CNPq). E-mail: carolina.falandes@unesp.br. ORCID: oooo-ooo1-6639-2121.
} 


\begin{abstract}
An imagetic generation is contemplated, which in the online world has the main support for the conduct of its interactive practices permeated by visualities. Protagonists of this media scenario, young people take advantage of various digital platforms to educate themselves, inform themselves, entertain themselves and exchange experiences between peers, mediated by multiple screens that overflow imagery content. With the objective of verifying how this population consumes and relates to digital images and their innovations, this study brings analyzes on a set of quantitative data collected through a survey, answered by 290 students. Among the results, the smartphone is the main communicational device, production photos is the favorite activity, Instagram - especially stories - is the most used network and the 360degree narratives seem inexpressive in youth routines.
\end{abstract}

Keywords: Digital Images; Virtual Social Networks; Youthes; Stories; 360 Degree Images.

\title{
Resumen
}

Se contempla una generación de imágenes, que en el mundo online tiene el principal soporte para la conducción de sus prácticas interactivas permeadas por visualidades. Protagonistas de este escenario mediático, los jóvenes aprovechan diversas plataformas digitales para educarse, informarse, entretenerse e intercambiar experiencias entre pares, mediado por múltiples pantallas que desbordan contenido de imágenes. Con el objetivo de verificar cómo esta población consume y se relaciona con las imágenes digitales y sus innovaciones, este estudio trae análisis sobre un conjunto de datos cuantitativos recolectados a través de una encuesta, respondida por 290 estudiantes. Entre los resultados, el teléfono inteligente es el principal dispositivo de comunicación, la preferencia por la producción de fotografías, Instagram, especialmente a través de stories, como la red más utilizada y la inexpresividad de las narrativas de 360 grados en las rutinas juveniles.

Palabras clave: Imágenes Digitales; Redes Sociales Virtuales; Jóvenes; Stories; Imágenes de 360 grados.

\section{Introdução}

Apoiando-se em um cenário tecnológico cada vez mais complexo, em torno do qual emergem inúmeras plataformas com interfaces amigáveis e projetadas para as diversas telas hoje disponíveis, a imagem digital se constitui uma linguagem de destaque, que vem reconfigurando as relações sociais e as formas de contar histórias na contemporaneidade. Historicamente, é perceptível a relação indissociável entre as visualidades e a trajetória humana - as representações pictóricas nas cavernas, a invenção da fotografia e do cinema são exemplos dessa proximidade - entretanto, uma nova ordem imagética foi instaurada a partir da digitalização, da democratização da 
Internet e do surgimento de dispositivos mais sofisticados, interativos e imersivos, elevando o processo comunicacional a um novo patamar. Diante de tamanha influência da imagem no cotidiano da sociedade, Fontcuberta (2016) pontua que o ser humano tem evoluído para a espécie homo photographicus, empoderada por um conjunto de câmeras de bolso com baixo custo e por celulares com câmeras acopladas, facilmente manipuláveis.

Nessa ecologia midiática atual, em que a lógica da convergência norteia as estratégias das plataformas digitais, oferecendo à audiência um labirinto de narrativas e possibilidades de participação, o jovem parece configurar-se como o principal ator, com potencial para contribuir de forma significativa no desenhar de uma cultura digital mais autônoma, sobretudo a partir do suporte das redes sociais virtuais. São nesses espaços, segundo Campos (2011), que as novas gerações, muitas vezes, constroem suas imagens públicas, sendo as fotografias e os vídeos fortes elementos de representação visual. Também, pode-se citar o entendimento que atribui aos jovens a função de público inicial quando do lançamento de produtos e serviços, dado o reconhecimento de ter grande receptividade às novas tecnologias (POMPEU; SATO, 2017).

É neste contexto de frequente mutação tecnológica que a presente pesquisa se insere, buscando verificar de que maneira o público jovem consome e se relaciona com as imagens digitais e suas inovações, de modo a trazer à tona hábitos imagéticos a partir de diferentes ambientes sociais, plataformas e aparelhos tecnológicos, bem como os estilos preferidos e cuidados estéticos quando da produção e consumo dos conteúdos.

Assim, o estudo em questão, ao ressaltar os comportamentos de jovens no meio digital, mapeando práticas que dizem respeito a relação desse público com as imagens, demonstra o compromisso de registrar um momento comunicacional histórico, em que as informações circulam numa velocidade exponencial e o avanço tecnológico permite à imagem assumir novas e variadas roupagens. Nesse sentido, a pesquisa fortalece seu caráter inovador por dar uma atenção especial para a relação dos jovens com a modalidade imagética 360 graus, ainda emergente, de acordo com estudo realizado anteriormente pelos autores envolvendo estudantes da cidade de Arica, no extremo norte do Chile (FALANDES; ANGELUCI, 2019a). Dessa forma, seguindo-se o mesmo protocolo e com uma amostra superior, pôde-se realizar esta investigação em São Caetano do Sul, município que fica na Região Metropolitana de São Paulo, Brasil.

Por meio da aplicação de um questionário on-line, foi possível levantar dados 
quantitativos sobre as práticas e preferências de jovens ao lidar com as imagens, organizando as análises a partir de quatro grupos temáticos: perfil, acesso, cultura da imagem e imagens em 360 graus. Como fundamentação teórica, esta pesquisa se ampara em reflexões sobre a relação dos jovens com as inovações tecnológicas, sobretudo relacionadas às imagens digitais e redes sociais virtuais.

\section{Geração imagética: o poder das visualidades sobre os jovens em tempos de redes sociais virtuais}

Pode-se dizer que na conjuntura midiática contemporânea, ver e ser visto, principalmente nas postagens das redes sociais virtuais, torna-se quase uma obrigação, processo que Buitoni (2016) entende como uma imposição da sociedade do espetáculo, em que ter visibilidade se transformou em sinônimo de existir. Nesse universo permeado por visualidades, o jovem parece marcar a vanguarda na adoção de determinadas tecnologias, podendo ser caracterizado como principal expoente dessa geração imagética. No entanto, deve-se ressaltar que as práticas imagéticas não são limitadas à juventude, uma vez que também são executadas por integrantes das demais faixas etárias - ou seja, muitos dos hábitos tecnológicos e imagéticos juvenis podem ser observados nas diversas faixas etárias que formam a sociedade contemporânea. Corroborando com esse entendimento, Buckingham (2013, p. 8-9, tradução nossa) avalia que apesar de as pessoas mais velhas, algumas vezes, serem apontadas como usuários tardios de tecnologias, nem sempre isso procede, "por exemplo, telefones celulares e microblogging (serviços como o Twitter) foram usados por adultos - ou pelo menos alguns grupos de adultos - muito antes de se tornarem populares entre os jovens".

Trazendo a discussão para os jovens, Oro (2018) reconhece os adolescentes como dominadores dessa nova cultura da imagem, uma vez que, por meio de aplicativos, editam os próprios conteúdos. Segundo Campos (2011), o jovem produz e compartilha imagens como um meio para se comunicar, construir identidades e representar a sua realidade. Assim, na atual ecologia midiática, esse público pode se servir de diferentes conteúdos visuais para contar suas histórias, como emoticons, GIFs e memes, itens disponíveis nas redes sociais virtuais. Além disso, tem nos dispositivos móveis diversos recursos que facilitam a criação das próprias imagens, a exemplo de aplicativos para edição de fotos e vídeos, bem como um número cada vez maior de plataformas para o compartilhamento de suas produções imagéticas. Dentre os hábitos 
mais comuns dos jovens nesses espaços, pode-se destacar as interações com os amigos, a divulgação de fotos e vídeos que registram momentos importantes, a busca de informações atualizadas e o acesso a conteúdos de entretenimento. Também, é importante ressaltar a preocupação com a imagem projetada para amigos e outros seguidores em perfis das redes sociais virtuais, como observaram Satler e Carrijo (2021, p. 126-127) em estudo feito com adolescentes no Instagram: "mostrar-se na rede, segundo os adolescentes, pode ser um exercício de autoconhecimento e posicionamento de si enquanto ser social”. Para as autoras, trata-se de um processo que envolve dinâmicas e performances ligadas à forma como o indivíduo quer ser visto e como se vê.

Ainda, tem se observado que jovens vêm consumindo cada vez mais conteúdos ao mesmo tempo, tanto por meio de múltiplas telas, como por buscas nas redes sociais virtuais. Essa prática tem exigido que as produções circulantes nos espaços on-line tenham formatos breves, a exemplo dos stories (Instagram e Facebook) e status (WhatsApp), criados para serem vistos rapidamente. Scolari (2019, p. 12, tradução nossa) considera esse fenômeno característico da cultura snack:

Nas últimas décadas inúmeras peças textuais curtas que fazem parte da chamada cultura snack se popularizaram: clipes, tweets, memes, trailers, mobisódio, webisódio, teasers, sneakpeaks, cápsulas informativas... até o malvado spoiler pode ser considerado uma espécie microtextual que circula e se reproduz de forma viral nas redes.

Pode-se dizer que o consumo crescente de conteúdos curtos está relacionado ao grande número de mídias disponíveis, como argumenta Scolari (2019, p. 11, tradução nossa): "se antes gastávamos muito tempo em poucas mídias, agora gastamos pouco tempo em muitas mídias”.

Entretanto, o fato de os jovens estarem conectados e interagirem em diversas mídias disponíveis na web - produzindo e/ou consumindo conteúdos - não necessariamente determina que sejam letrados digitalmente, gerando, inclusive, discussões sobre a real influência desse público sobre as inovações tecnológicas, ou seja, se estas ocorrem para responder aos interesses da juventude ou por uma questão econômica, buscando ter cada vez mais controle dos dados e, por consequência, manipular os comportamentos dos usuários. É por essas e outras ambivalências que estudos recentes têm atentado para os problemas inerentes à cultura digital, como a perda de valores de privacidade em meio à vigilância ubíqua e invisível das plataformas (SANTAELLA, 2015; KERCKHOVE, 2015). Por outro lado, pesquisas também têm 
evidenciado a existência de múltiplas juventudes - para além das tecnologias - que refletem as diferenças sociais, culturais, econômicas e geográficas presentes na sociedade. Campos (2010, p. 122) descreve que essas juventudes "se dispersam pelo espaço geográfico e social, confrontam-se com problemas, condições e expectativas distintas, assumem configurações peculiares”. Da mesma forma, essas circunstâncias são observadas na juventude conectada brasileira, que, de acordo com a Fundação Telefônica (2014, p. 209), "não é homogênea e nem tampouco consensual". No entanto, Passarelli (2020, p. 4) afirma que "mesmo com todas as diferenças, um dos pontos de intersecção entre todos os possíveis subgrupos da juventude é o alto uso de tecnologia”.

Nessa perspectiva, várias expressões buscam classificar o público jovem levando em consideração suas características, competências e relações com as tecnologias, a exemplo de millennials (STRAUSS; HOWE, 1991), geração Net (TAPSCOTT, 1998), geração @ (FEIXA, 2000), nativos digitais (PRENSKY, 2001) e geração interativa (PASSARELLI; JUNQUEIRA; ANGELUCI, 2014), termos presentes na literatura e que são passíveis de discussão sobre seus limites e abrangências, uma vez que podem não abarcar as diversidades das juventudes. Na visão de Feixa (2000, p. 87, tradução nossa), criador do termo "geração @”, nomenclatura que retrata a primeira geração do século XXI, "as gerações não são estruturas compactas, mas apenas referentes simbólicos que identificam vagamente os agentes socializados nas mesmas coordenadas temporais".

Para além desses debates, não se pode desconsiderar que múltiplos caminhos midiáticos se interpõem no cotidiano de grande parte da população jovem, potencializando suas estratégias de comunicação e interação, que são realizadas, sobretudo, por meio de imagens. Nesse contexto, as tecnologias móveis, em especial os smartphones, têm impulsionado o uso acentuado das redes sociais virtuais, ambientes em que todos podem ser prosumers (TOFFLER, 1980). Baitello Junior (2015, p. 20) descreve esses espaços como telas de repetição, pois repercutem sempre os mesmos conteúdos, o que leva à saturação da mensagem. O autor explica: "o não-fazer-nadarelevante é destacado quando o registro do nada feito nas máquinas que o repetem e reverberam transformam-no em uma grandeza mensurável: tantas pessoas curtiram, aqui estão seus nomes".

Dessa forma, os jovens se apropriam de perfis virtuais para compartilhar imagens que representam suas atividades cotidianas, sempre atentos às reações dos 
seguidores sobre os conteúdos. Para atuar nessa cultura da imagem, essa geração é favorecida por uma "cultura do software" (MANOVICH, 2013), responsável por lhe abastecer com um leque de ferramentas digitais que a auxiliam em suas produções. Trata-se de um ecossistema midiático conduzido por interfaces, pelas quais se desenvolvem trocas comunicativas a partir de diferentes recursos tecnológicos, em constante renovação. Nessa perspectiva, estudos vêm demonstrando a ampla adesão dos jovens em relação às redes sociais virtuais, mapeando seus usos e apropriações. Como exemplo, pode-se citar o relatório da pesquisa TIC Domicílios 2017 (CGI.br, 2018), que, dentre os resultados, aponta as imagens autorais como os conteúdos mais publicados na Internet, além de revelar que a produção de fotos pelo celular é mais comum pelos nativos digitais.

Se por um lado existem muitas investigações que se dedicam a medir o impacto das TICs no cotidiano dos jovens, por outro nota-se uma escassez de publicações em relação aos hábitos desse público com a imagem em 360 graus, modalidade que permite a quem observa ver o ambiente capturado por completo. Longhi (2019) avalia que esse tipo de conteúdo evidencia uma quebra de paradigma na lógica das imagens tradicionais, pois rompe os limites do quadro. Dessa forma, trata-se de uma inovação tecnológica com grande potencial narrativo, que integra a gama de possibilidades imagéticas do cenário contemporâneo, logo, é fundamental verificar as conexões do público jovem com essa modalidade.

Pôde-se nortear o atual estágio de consumo das imagens em 360 graus pelos jovens a partir de estudos realizados pelos autores deste artigo: um com estudantes da cidade de Arica, no Chile (FALANDES; ANGELUCI, 2019a), e outro referente à produção de uma narrativa audiovisual 360 graus, feita em colaboração com universitários de São Caetano do Sul (SP), no Brasil (FALANDES; ANGELUCI, 2020). Os jovens que foram voluntários na produção audiovisual nunca tinham utilizado uma câmera 360 graus, desconheciam o processo de captação e edição dessas imagens e não eram consumidores desse tipo de conteúdo nas mídias, apesar de já terem visto algumas obras. Dessa forma, foram convidados a captar e editar as próprias imagens, sendo parte delas exploradas no produto. Tecnicamente, os participantes responderam de forma eficaz aos processos de aprendizagem, tanto no que se refere ao uso da câmera 360 como aos softwares de edição. Deve-se ressaltar que os colaboradores eram estudantes de comunicação. 
Em outro estudo, os autores analisaram imagens em 360 graus publicadas no Instagram a partir de hashtags relacionadas à modalidade imagética 360 graus, constatando-se que os conteúdos identificados, em sua quase totalidade, eram fotos/vídeos do tipo "little planet" produzidos por empresas especializadas, com propósitos de divulgação de produtos (FALANDES; ANGELUCI, 2019b). Logo, a produção desses conteúdos estava concentrada fora do alcance popular.

Com base no panorama apresentado, evidencia-se a importância de pesquisas mais robustas que possam mostrar dados e discutir motivos pelos quais a tecnologia 360 graus ainda está distante do cotidiano dos jovens, reconhecidamente os principais consumidores de imagens na atualidade.

\section{Metodologia}

Para o desenvolvimento desta pesquisa, seguiu-se a metodologia de levantamento (survey), técnica caracterizada pela solicitação de informações acerca de determinado tema para uma quantidade considerável de pessoas, com o objetivo de alcançar os resultados após a leitura e interpretação estatística dos dados (GIL, 2010). Assim, distribuiu-se um questionário on-line via Formulário Google, respondido por 290 alunos de duas instituições privadas, uma de ensino médio e outra superior, localizadas em São Caetano do Sul, Região Metropolitana de São Paulo. A coleta foi possível a partir da realização de eventos nos estabelecimentos de ensino, mobilizandose voluntários para responder à pesquisa por meio dos próprios smartphones. Deve-se ressaltar que o lócus desta investigação apresenta o melhor Índice de Desenvolvimento Humano (IDH) do Brasil (PNUD, 2013), ocupa a sexta posição no ranking das cidades mais inteligentes e conectadas do país e o primeiro lugar em Educação (RANKING CONNECTED SMART CITIES, 2020), particularidades que podem remeter à existência de uma população jovem mais próxima às tecnologias. Na esteira dessa reflexão, o relatório Juventude Conectada sustenta que as práticas digitais dos jovens brasileiros "parecem revelar um significativo vínculo com o conjunto de valores e sensibilidades decorrentes da urbanização/metropolização das cidades onde vivem esses jovens" (FUNDAÇÃO TELEFÔNICA, 2014, p. 81). Dessa forma, acredita-se que os resultados do levantamento feito em São Caetano do Sul podem evidenciar um dos maiores índices de penetração tecnológica do país, inclusive servindo como termômetro para medir o nível em que se encontram as imagens em 360 graus no cotidiano dos jovens. 
Passarelli (2020) salienta que as múltiplas faces da juventude brasileira nunca estarão plenamente apontadas em um relatório de pesquisa, tampouco caberia limitar a juventude a uma parcela da sociedade com faixa etária de 15 a 29 anos, conforme estabelece a legislação. Sendo assim, a autora afirma que a única chance de uma aproximação mais precisa dos anseios dessa classe "é conduzir pesquisas com vistas às fases de desenvolvimento social nos locais mais variados” (PASSARELLI, 2020, p. 3). Assim, o presente estudo não tem pretensões de determinar um perfil universal para os jovens, mas sim apresentar um retrato da realidade de uma parte destes. A coleta de dados ocorreu nos dias 14, 15, 20, 21 e 23 de maio de 2019, compreendendo participantes com idades entre 15 e 24 anos, faixa etária mais conectada em todo o mundo, de acordo com o Fundo de Emergência Internacional das Nações Unidas para a Infância (UNICEF, 2017).

O instrumento de coleta aplicado, um survey com 19 perguntas, foi testado em um trabalho preliminar (FALANDES; ANGELUCI, 2019a) e se mostrou eficaz. Sua estrutura alterna questões de resposta curta, múltipla escolha, caixas de seleção e grade de múltipla escolha. A organização do questionário foi pensada com o objetivo de conhecer aspectos que cercam a relação dos jovens com as imagens digitais e suas inovações, sendo apresentados neste artigo resultados pertinentes a todas as questões, estendendo a análise aos mais significativos. Os dados foram analisados com o apoio de cálculos estatísticos, como porcentagens e médias, valendo-se de gráficos em alguns casos para favorecer a compreensão das conclusões, além da comparação de resultados com estudos anteriores.

\section{Análise e discussão dos resultados}

Os dados quantitativos apurados foram classificados em quatro grupos: 1. Perfil, formado por seis questões relacionadas a informações pessoais dos respondentes, como idade e escolaridade; 2. Acesso, composto por quatro questões direcionadas a investigar quais aparelhos tecnológicos os jovens possuem e a quantidade de horas que estes ficam conectados na web em diferentes dispositivos; 3. Cultura da imagem, que integra seis questões sobre os hábitos imagéticos dos respondentes, como tipos de conteúdo mais vistos e plataformas onde mais compartilham imagens; e 4. Imagens em 360 graus, com três questões acerca da relação dos jovens com essa tecnologia, envolvendo a frequência que veem esse tipo de imagem, níveis de interação e sensações que lhes despertam. 


\section{Perfil}

Pôde-se constatar que dos 290 respondentes, 48\% eram estudantes do ensino médio e $52 \%$ do ensino superior, ambos de instituições privadas. Sobre o gênero, $56 \%$ indicaram ser do sexo masculino e $44 \%$ do feminino. Do total de participantes, $57 \%$ moram em São Caetano do Sul. A quase totalidade, 94\%, declarou morar com os pais, situação que pode ser explicada pelo fato de parte dos jovens ainda serem estudantes do ensino médio e dependentes dos pais. Da mesma forma, os jovens universitários também têm permanecido com os pais por mais tempo, o que na visão de Sawyer, Azzopardi, Wickremarathne e Patton (2018) está alinhado a fatores como o término dos estudos e casamento. É importante esclarecer que se optou por não analisar as amostragens por nível de escolaridade - ensino médio e superior -, e sim de forma integrada, seguindo-se a faixa etária de 15 a 24 anos.

\section{Acesso}

No que se refere ao acesso a aparelhos tecnológicos nas residências dos jovens, podendo-se selecionar mais de uma opção, conforme Gráfico 1, apurou-se que 96\% dos respondentes têm smartphone. Este resultado vai ao encontro de diversas publicações que apontam a preferência por este dispositivo, como a PNAD Contínua TIC 2018 (IBGE, 2020) e o relatório TIC Domicílios 2019 (CGI.br, 2020). A importância deste equipamento para os jovens pode ser explicada por sua capacidade de integrar diferentes recursos, com a centralização de várias atividades antes díspares, otimizando as tarefas. Nos termos de Scolari (2016, p. 183), "a comunicação móvel está no centro dos processos de convergência cultural contemporâneos”.

Gráfico 1 - Aparelhos tecnológicos dentro da residência 


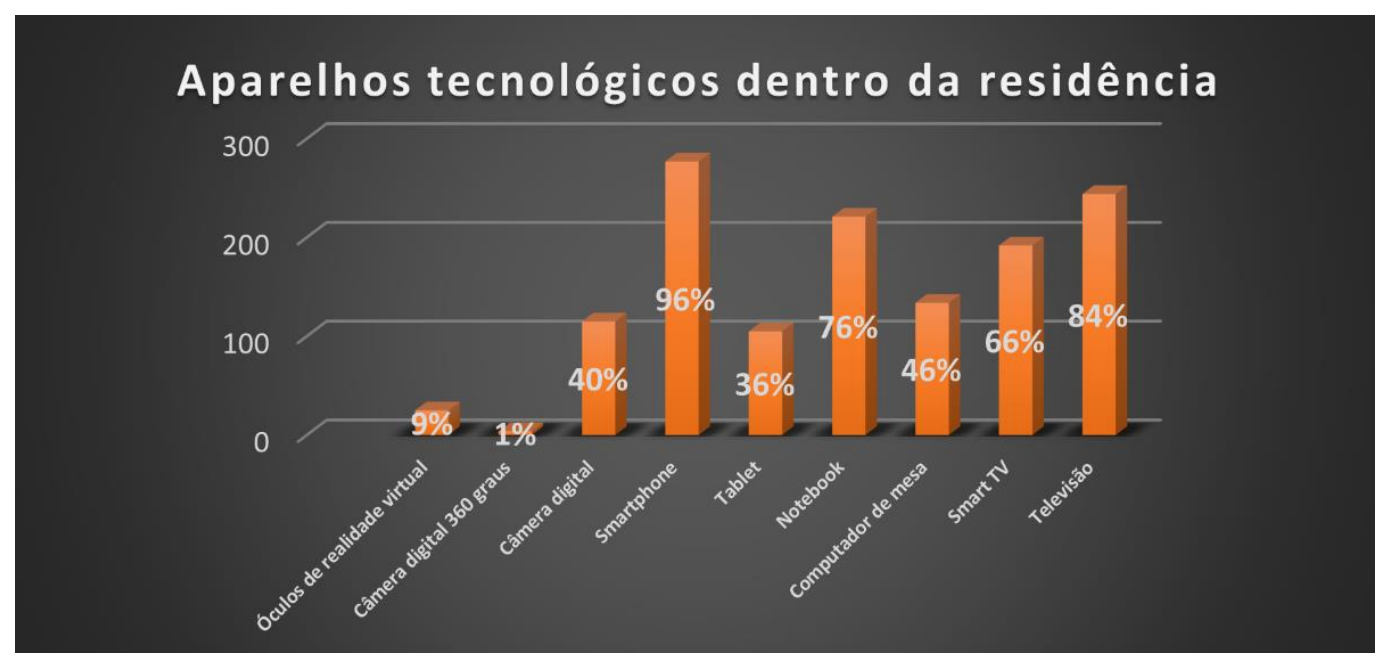

Fonte: Elaborado pelos autores (2021).

O Gráfico 1 ainda destaca que a televisão, indicada por $84 \%$ dos jovens, foi o segundo aparelho mais presente nas residências, seguido pelo notebook, citado por 76\% dos participantes, e pela smart TV, com 66\% das menções. Deve-se ressaltar a tendência de crescimento do uso da smart TV, como revela a pesquisa TIC Domicílios 2018 (CGI.br, 2019), ao afirmar que nos próximos anos esse aparelho poderá ocupar a segunda posição no ranking dos dispositivos de acesso à Internet. Nesse sentido, justifica-se esse crescimento pelos hábitos imagéticos atuais, em que se tornou comum utilizar a TV para assistir a filmes, séries e demais conteúdos na web, ao mesmo tempo que é possível usar simultaneamente outras telas. Na sequência dos resultados, aparecem computador de mesa, com 46\% das menções, câmera digital, mencionada por $40 \%$ dos jovens e tablet, apontado por 36\%. Ainda, pôde-se constatar que apenas uma minoria tem em casa óculos de realidade virtual e câmera digital 360 graus.

O estudo também procurou saber o total de horas que os jovens ficam na Internet utilizando smartphone, notebook e computador de mesa (PC), com a possibilidade de escolher entre o e 24 horas diárias. Em relação ao smartphone, apurou-se que 180 estudantes ficam de 3 a 10 horas diárias na Internet, sendo que 42 destes - a maior concentração - afirmaram passar 4 horas conectados por dia. No caso do notebook, observou-se que 125 jovens não acessam a Internet por esse dispositivo e 109 utilizam-no por um período de 1 a 3 horas diárias, sendo que 51 destes - a maior concentração - revelaram ficar 1 hora por dia. Sobre o uso de computador de mesa (PC), 125 declararam não utilizar esse dispositivo e 139 acessam a Internet pelo mesmo no período de 1 a 8 horas diárias, sendo que 43 destes - a maior concentração - ficam 1 hora por dia conectados. A leitura desses resultados coloca o smartphone como o 
principal dispositivo que os jovens utilizam para acessar a Internet, corroborando dados apurados na pesquisa TIC Kids Online 2020 (CGI.br, 2021), a mais recente - e mais importante no Brasil - sobre o assunto.

\section{Cultura da imagem}

A análise dos dados referentes ao grupo cultura da imagem trouxe um retrato sobre a relação dos jovens com conteúdos imagéticos. Primeiramente, pôde-se verificar que os conteúdos mais vistos foram os memes, apontados por $44 \%$ dos respondentes. Na sequência, ficaram as fotos tradicionais (31\%) e os vídeos tradicionais (24\%). GIFs, fotos em 360 graus e vídeos em 360 graus obtiveram resultados inexpressivos. $\mathrm{O}$ interesse dos jovens pelos memes pode ser justificado pelo fato de essas produções atuarem como breves conteúdos e falarem a linguagem de um grupo. Também, podem ser analisados sob o ponto de vista de Calixto (2017), que os avalia como uma forma de os estudantes construírem relacionamentos sem a dependência do aval dos responsáveis. Da mesma forma, essas narrativas podem ser classificadas dentro da cultura snack, uma vez que são narrativas breves (SCOLARI, 2019).

Para apurar os locais onde os jovens mais consomem imagens, foi aplicada uma escala de o a 10, em que o significa "não consumir" e 10 "consumir muito". Os respondentes puderam atribuir notas para diferentes espaços sociais indicados no questionário. O espaço "em casa”, citado por 157 jovens, configurou-se como o local em que os estudantes mais consomem imagens. Em seguida, ficou a "casa de amigos", com 111 apontamentos. O terceiro espaço mais escolhido foi a "escola/universidade intervalo", mencionada por 108 participantes. Na sequência, vieram "nos intervalos do trabalho" (97 menções), "em deslocamento" (96 menções), "na sala de aula" (79 menções) e "em horário de trabalho" (59 menções). Deve-se ressaltar que todos esses valores representam um consumo que vai de regular a alto. A escolha dos três espaços mais votados pelos jovens para consumir imagens, "em casa", "casa de amigos" e "escola/universidade - intervalo", pode estar alinhada ao acesso à Internet a partir de rede wi-fi, fato também observado na TIC Domicílios 2018 (CGI.br, 2019), cujos resultados mostram a preferência dos usuários por utilizar a Internet em casa ou na casa de outras pessoas.

Com relação aos conteúdos imagéticos que os jovens mais produzem (Gráfico 2), as fotos tradicionais receberam a maior parte das menções (69\%), seguidas pela opção de não se produzir imagens (18\%), memes (7\%), vídeos tradicionais (4\%) e GIFs 
(2\%). Para as fotos em 360 graus, observou-se uma indicação $(0,3 \%)$ e os vídeos em 360 graus não foram citados.

Gráfico 2 - Conteúdos produzidos pelos jovens

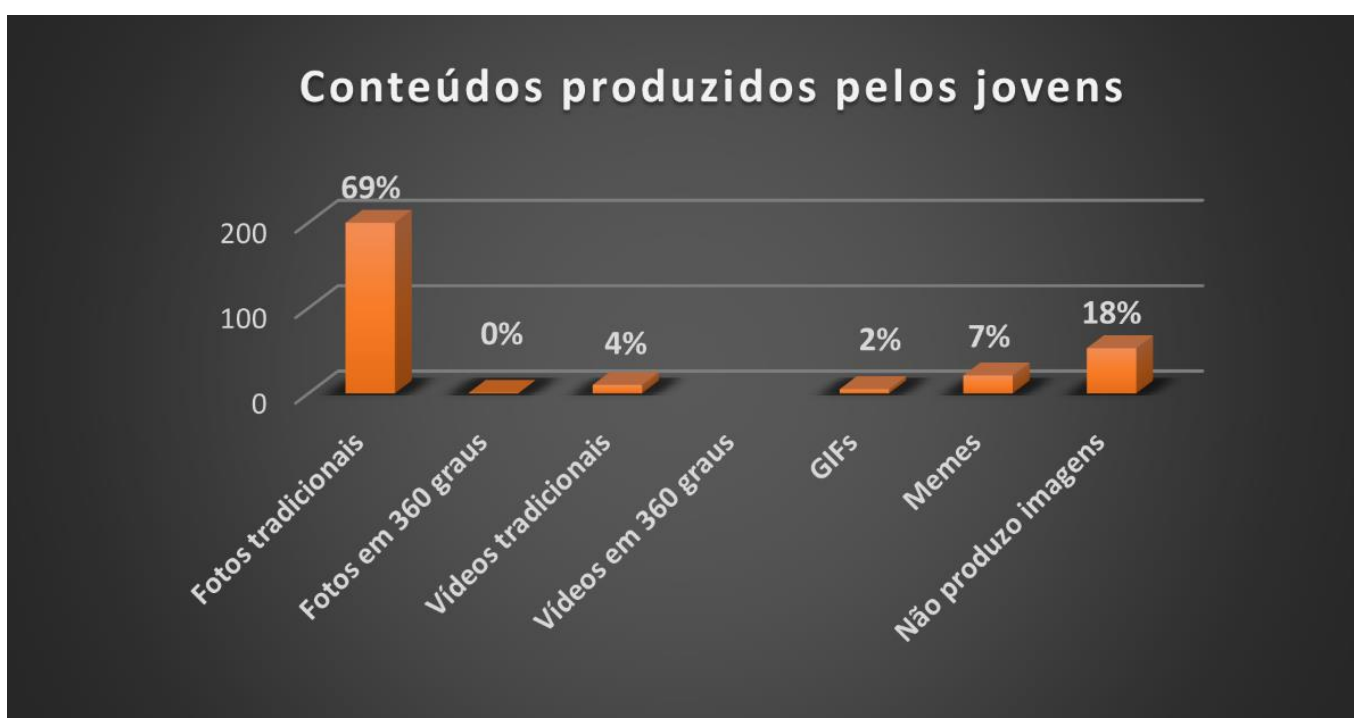

Fonte: Elaborado pelos autores (2021).

Pode-se justificar a preferência dos respondentes pela produção de fotos tradicionais como um reflexo da democratização dos smartphones, que apresentam câmeras integradas, facilitando a criação e divulgação instantânea dos conteúdos. Esse resultado se alinha ao do relatório da pesquisa TIC Domicílios 2017 (CGI.br, 2018), que destacou os nativos digitais como os maiores produtores de fotos pelo celular. Ao mesmo tempo, observou-se um percentual significativo de jovens que não produzem imagens, são apenas consumidores. Também ficou evidente o distanciamento dos participantes em relação à produção de conteúdos em 360 graus.

Ao se investigar as rotinas produtivas dos jovens no que se refere às imagens, constatou-se que 40\% dos respondentes afirmaram criar e editar conteúdos imagéticos pelo smartphone, compartilhando-os imediatamente, ao passo que 29\% disseram criar pelo smartphone e compartilhar na mesma hora, sem se preocupar em fazer edições. Também, 17\% não produzem imagens - confirmando dado apurado anteriormente -, enquanto $7 \%$ do público investigado cria e edita as imagens pelo smartphone, sem compartilhar. Na sequência, 3\% afirmaram utilizar o smartphone, mas levam as produções para editar no computador ou notebook, daí sim compartilham. Outros 3\% preferem usar câmera digital e 1\% dos respondentes criam pelo smartphone, editam no computador ou notebook e não compartilham as imagens. Assim, a leitura desses 
resultados demonstra a opção de parcela considerável dos jovens pela criação, edição e compartilhamento instantâneo de imagens por meio do smartphone, aplicando efeitos estéticos presentes nos aplicativos móveis. Notou-se ainda participantes que declararam não realizar edições quando da criação e compartilhamento de imagens a partir do smartphone, tendo um maior interesse em registrar os acontecimentos. Deve-se destacar também os que são apenas consumidores de imagens, além dos que não compartilham as imagens produzidas e editadas, evidenciando princípios como memória e privacidade.

Sobre a qualidade técnica das produções, $40 \%$ dos jovens alegaram se preocupar às vezes, atentando-se para o enquadramento e edição, e $24 \%$ disseram não ter preocupação com isso. Por outro lado, $21 \%$ dos respondentes têm essa preocupação constantemente, de forma a procurar os enquadramentos mais adequados para suas fotos e vídeos, acrescentando recursos disponíveis, a exemplo de filtros e textos, ao passo que $15 \%$ dos participantes não são produtores de conteúdos imagéticos. De modo geral, pôde-se concluir que a maioria dos jovens têm preocupação com a qualidade das imagens, em maior ou menor intensidade, o que pode ter relação com a imagem de si que desejam projetar, logo, zelam por sua reputação. Nesse sentido, Recuero (2009) considera que a reputação pode ter ligação com a qualidade e relevância das informações divulgadas na rede, e afirma que o usuário pode, no futuro, tornar essa reputação uma forma de capital, apoiando-se, para isso, em recursos como a fama e anúncios em seus blogs. No mesmo caminho, Satler e Carrijo (2021, p. 120) destacam que a construção do eu é um processo constante: "a necessidade de construir uma autoimagem, ou mais, para relacionar-se com os outros confere ao sujeito contemporâneo múltiplas possibilidades e exige ajustes performáticos específicos para controlar as impressões deixadas".

A plataforma mais utilizada pelos jovens para compartilhar suas imagens, conforme Gráfico 3, é o Instagram, a partir do recurso stories, com 36\% dos votos. Em segundo lugar, com $20 \%$ das menções, foi escolhida a linha do tempo desta mesma rede social. Em terceiro lugar, citado por $16 \%$ dos jovens, ficou o recurso status do WhatsApp, enquanto na quarta posição foi citada por 11\% dos participantes a opção de mensagens desse mesmo aplicativo. Na quinta posição, $7 \%$ dos jovens declararam não compartilhar imagens, ao passo que a sexta posição foi ocupada pela linha do tempo do Facebook, com 6\% dos votos. Em sétimo lugar ficou o Twitter, que recebeu 3\% das menções, e os stories do Facebook ficaram com a oitava posição, com 1\% das citações. 
Ainda, constatou-se que as plataformas YouTube, Vimeo, Pinterest e Flickr não foram selecionadas.

\section{Gráfico 3 - Locais onde os jovens compartilham imagens}

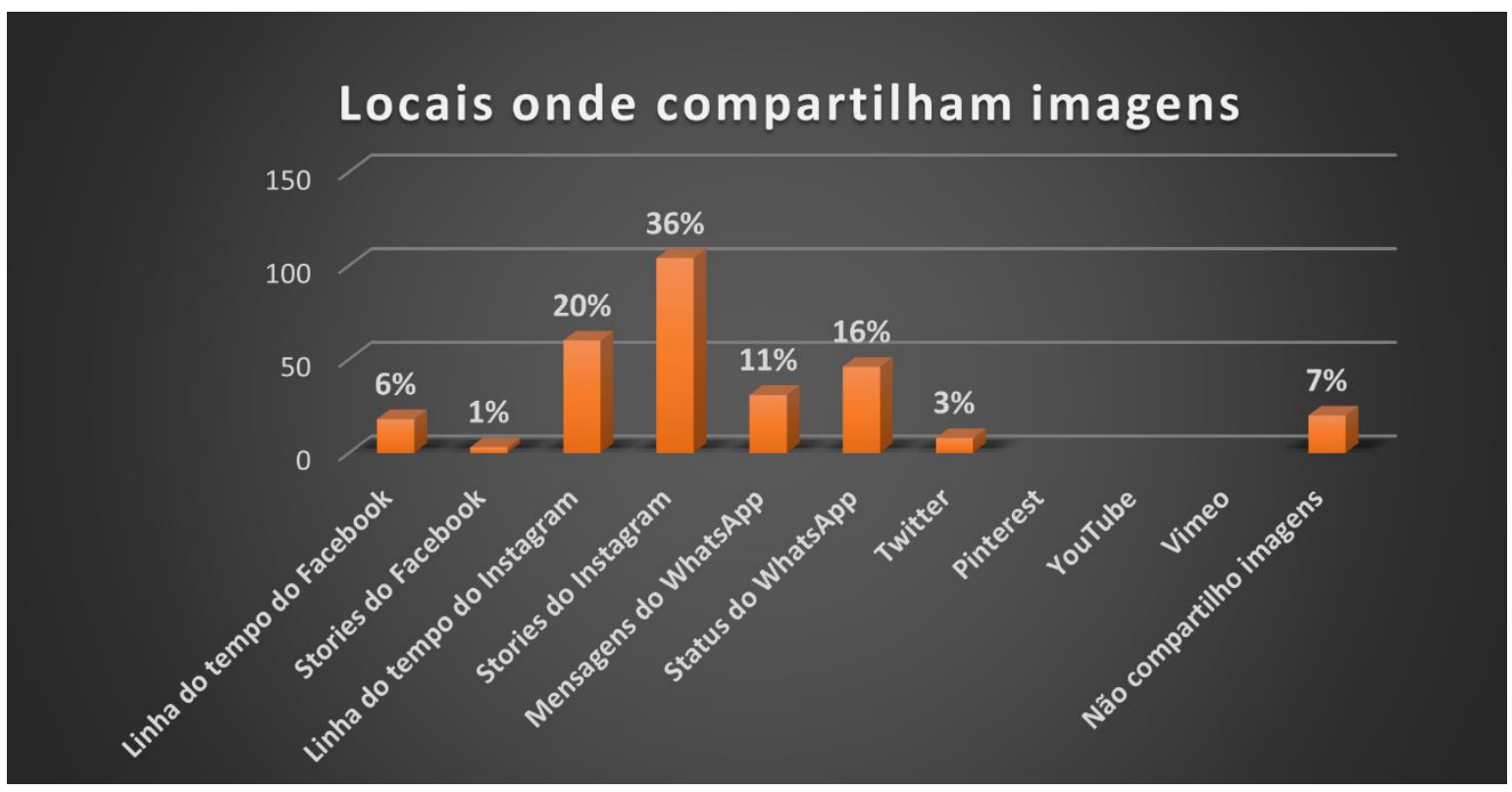

Fonte: Elaborado pelos autores (2021).

A análise dos espaços onde os jovens compartilham imagens evidenciou a preferência pelo uso dos recursos de imagens temporárias presentes no Instagram (stories) e no WhatsApp (status). Essas escolhas, mais uma vez, denotam que os jovens têm optado por compartilhar narrativas breves, caracterizando a cultura snack, preconizada por Scolari (2019). Observou-se também a consolidação do Instagram como a plataforma favorita do momento, superando redes sociais virtuais tradicionais, como YouTube e Facebook. Pode-se considerar essa movimentação do ranking das redes sociais virtuais mais utilizadas como um reflexo dos constantes avanços tecnológicos, que impulsionam a criação/renovação das plataformas e, ao mesmo tempo, o deslocamento das audiências. Como consequência desse efeito cascata, Medeiros (2018) prevê que as novas possibilidades tecnológicas vão acarretar transformações nas práticas interacionais dos jovens com os meios e com o próximo, além de influenciar nos modos pelos quais constroem conhecimento, o que exige olhares científicos rotineiros para acompanhar essas mutações.

\section{Imagens em 360 graus}


Com o objetivo de investigar em que medida os jovens se deparam com conteúdos em 360 graus (fotos e vídeos), uma das inovações imagéticas contemporâneas, constatou-se que 66\% dos participantes raramente encontram esses conteúdos e 15\% afirmaram vê-los quase sempre. Entretanto, 11\% dos respondentes nunca se depararam com essas produções, enquanto 8\% não souberam responder e apenas um jovem afirmou sempre ver esse tipo de imagem. Os resultados extraídos desta questão mostram a pouca expressividade dos conteúdos imagéticos em 360 graus na $w e b$ e dialogam com o que foi apurado nos grupos das perguntas referentes ao acesso e à cultura da imagem, conforme demonstrado no Quadro 1.

Quadro 1 - Resultados levantados nos grupos temáticos “acesso" e “cultura da
imagem”

Fonte: Elaborado pelos autores (2021).

Os dados referentes ao grupo temático "acesso" mostram que dos 290 respondentes, apenas quatro possuem câmera $360^{\circ}$ (1\%) e 25 dispõem de óculos de realidade virtual (9\%) dentro de suas residências. Em relação ao grupo "cultura da imagem", somente um participante declarou consumir mais fotos em 360 graus, um disse consumir mais vídeos em 360 graus, um afirmou produzir mais fotos em 360 graus e nenhum produz vídeos em 360 graus. A quantidade de óculos de realidade virtual (25), que destoa dos demais resultados, pode ter relação com o consumo de jogos, prática geralmente comum à faixa etária analisada.

O cenário apresentado reflete o caráter emergente desta tecnologia, cujas características peculiares de produção, edição e divulgação - como o custo alto dos equipamentos e exigência de grande velocidade de Internet - acabam se tornando 
barreiras para que os jovens possam acessar esta modalidade. Tal fato contrasta com a ecologia imagética atual, dominada pelas lógicas dos dispositivos móveis, com funções que permitem a produção de imagens tradicionais de forma fácil, rápida e instantânea.

Sobre a reação dos jovens quando visualizam conteúdos em 360 graus, verificou-se que $43 \%$ afirmaram interagir pouco, $34 \%$ interagem muito e $12 \%$ não interagem. Já 11\% disseram nunca observar esse tipo de conteúdo, o que confere com o percentual daqueles que "nunca se depararam" com essas produções (dado levantado anteriormente), podendo-se inferir que se trata dos mesmos respondentes e que estes nunca viram uma imagem 360 graus. Com base nos resultados, percebe-se que a maioria dos jovens entrevistados procura interagir - pouco ou muito - quando se depara com fotos e vídeos em 360 graus, denotando que essa população tem curiosidade sobre essa modalidade.

Com relação às sensações que as imagens em 360 graus despertam nos jovens investigados, como demonstrado no Gráfico 4, constatou-se que $45 \%$ têm curiosidade e vontade de interagir, enquanto $30 \%$ se sentem dentro da imagem. Já $21 \%$ dos respondentes afirmaram que essas produções não lhes despertam nada e 4\% sentem estranheza ao ver esse tipo de conteúdo. Deve-se ressaltar que todos os participantes da pesquisa responderam ao questionamento sobre as sensações despertadas pelas imagens 360 graus. Assim, deduz-se que a maioria dos jovens que escolheram a opção "não me despertam nada" (21\%) podem representar os grupos que, anteriormente, apontaram "nunca se depararam" (11\%) e "não souberam responder" (8\%) para indicar em que medida encontravam conteúdos em 360 graus - ou seja, aquilo que não se vê e não se conhece, parece não despertar nenhuma sensação. No entanto, trabalhos futuros podem ser conduzidos de modo a ampliar o leque de opções, favorecendo um diagnóstico mais preciso.

\section{Gráfico 4 - Sensações que as imagens em 360 graus despertam nos jovens}




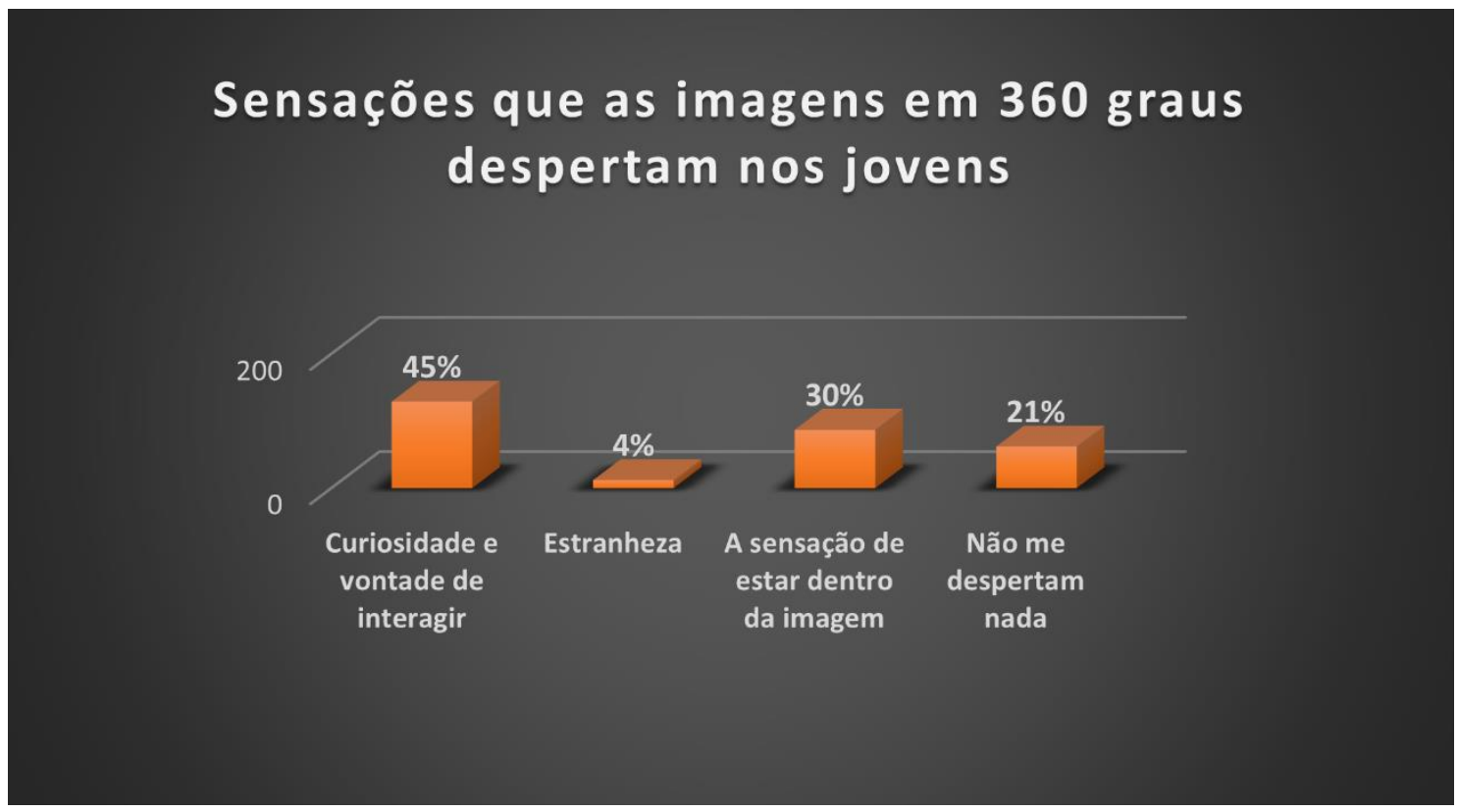

Fonte: Elaborado pelos autores (2021).

Ainda, pôde-se observar que, para boa parte dos jovens, os conteúdos em 360 graus despertam sensações que incentivam a interação e a imersão, características estimuladas por essa tecnologia. Por outro lado, uma fatia dos participantes aponta sensações que podem indicar indiferença, estranheza ou desconhecimento em relação a essas produções. Nesse sentido, para além das dificuldades de acesso aos equipamentos - que ainda têm custos elevados para a realidade dos jovens brasileiros - é importante discutir outros fatores que podem influenciar a popularização da modalidade 360 graus, como: 1 . A falta de tempo dos usuários para interagir com fotos e vídeos em 360 graus, pois, de acordo com Claremont (2019, p. 14, tradução nossa), os usuários acessam as redes sociais virtuais "na velocidade da luz", aspecto também frisado por Scolari (2019) quando caracteriza a cultura snack; 2. A necessidade de investimentos de forma permanente pelas empresas de mídia para a popularização dessa tecnologia; 3. Carência de produções nas redes sociais virtuais, o que foi evidenciado nesta investigação; 4. A intensificação de estudos dedicados à análise dos elementos que mais influenciam o jovem na adesão ou não dessa tecnologia - tanto no circuito acadêmico, como em laboratórios de inovação das mídias -, buscando responder os motivos pelos quais alguns a adotam e outros não se mostram interessados, de forma a aprofundar dados levantados nesta pesquisa.

Além desses fatores, talvez o grande teste para saber se essa tecnologia pode explodir no gosto juvenil será a possibilidade de o smartphone acoplar todos os recursos necessários para a produção das imagens em 360 graus, uma vez que 96\% dos 
jovens investigados têm acesso a esse dispositivo e 80\% destes se declararam produtores de imagens por meio do smartphone.

\section{Considerações finais}

É importante ponderar que não foi propósito desta pesquisa apontar dados universais sobre a relação da população jovem com as imagens digitais, uma vez que, apesar dos avanços referentes ao acesso à Internet e as demais tecnologias nos últimos anos, diferenças sociais significativas ainda se interpõem nos processos comunicacionais e informacionais. Também, diante de um cenário midiático em constante mutação, com plataformas - e audiências - que se renovam apressadamente, torna-se desafiador para o campo científico acompanhar essa velocidade. Como exemplo, pode-se citar o aplicativo TikTok, voltado para o compartilhamento de vídeos curtos, que quando do período da coleta de dados não tinha a força que atingiu posteriormente entre os jovens brasileiros.

Dentre os resultados apurados merece destaque o smartphone como o aparelho mais presente nas residências dos jovens e o mais utilizado para acessar à Internet, produzir e compartilhar imagens. Ainda, os memes são os conteúdos mais vistos e as fotos tradicionais os mais produzidos, sendo o Instagram a rede social virtual onde mais compartilham imagens, sobretudo via stories. Vale ressaltar o protagonismo assumido pelas imagens temporárias também observado no WhatsApp (status). "Em casa” projetou-se como o local onde os jovens mais consomem imagens. Ademais, foi percebida a inexpressividade de consumo e produção de imagens em 360 graus.

Em síntese, os dados coletados por ocasião da presente pesquisa colaboram de forma significativa para a absorção dos comportamentos de adolescentes e jovens quando de suas práticas imagéticas, abordagem atualizada e em consonância com o domínio do visual que impera na sociedade contemporânea. Ainda, a partir das considerações sobre o estágio em que se encontram o consumo e a produção das imagens em 360 graus, espera-se contribuir para uma maior reflexão sobre essa modalidade imagética, ainda restrita, em grande parte, a profissionais, e que emana uma diversidade de variáveis carentes de estudos no sentido de explicar sua pouca adesão no cotidiano dos jovens, envolvendo discussões como a necessidade de investimentos por parte das plataformas, o barateamento das tecnologias envolvidas e a consolidação de uma linguagem. 


\section{Referências}

BAITELLO JUNIOR, N. (A massa sem corpo), (o corpo sem massa), (a massa sem massa), (o corpo sem corpo). As redes sociais como ambientes de ausência (e fundamentalismos). In: LOPES, M. I. V.; KUNSCH, M. K. (org.). Comunicação, cultura e mídias sociais. São Paulo: ECA-USP, 2015, pp. 17-22. Disponível em:

http://www.assibercom.org/arquivos/o2_congresso_ibercom_2015.pdf. Acesso em: 30 nov. 2020.

BUCKINGHAM, D. Making Sense of the 'Digital Generation': Growing Up with Digital Media. Self \& Society, v. 40. n. 3, p. 7-15, 2013. Disponível em:

https://www.tandfonline.com/doi/abs/10.1080/03060497.2013.11084274. Acesso em: 20 ago. 2021.

BUITONI, D. S. Imagem, identidade e espetáculo. In: MORAES, A. L. C.; COELHO, C. N. P. (org.). Cultura da imagem e sociedade do espetáculo. 1.ed. - São Paulo: UNI, 2016, pp. 71-99.

CALIXTO, D. O. Memes na internet: entrelaçamentos entre educomunicação, cibercultura e a 'zoeira' de estudantes nas redes sociais. Dissertação (Mestrado em Ciências da Comunicação) - Universidade de São Paulo, São Paulo, 2017. Disponível em: https://www.teses.usp.br/teses/disponiveis/27/27154/tde-01112017102256/publico/DOUGLASDEOLIVEIRACALIXTO.pdf. Acesso em: 25 jan. 2021.

CAMPOS, R. A imagem digital como forma de comunicação e produção cultural juvenil na metrópole. In: Anais do XI Congresso Luso Afro Brasileiro de Ciências Sociais, Diversidades e (Des)igualdades. Salvador, UFBA, 2011.

CAMPOS, R. Juventude e visualidade no mundo contemporâneo: uma reflexão em torno da imagem nas culturas juvenis. Sociologia, Problemas e Práticas, n. 63, pp. 113-137, 2010. Disponível em: http://www.scielo.mec.pt/pdf/spp/n63/n63a07.pdf. Acesso em: 02 maio. 2021.

CGI.br - Comitê Gestor da Internet no Brasil. TIC Domicílios 2017: Pesquisa Sobre o Uso das Tecnologias de Informação e Comunicação nos Domicílios Brasileiros. Núcleo de Informação e Coordenação do Ponto BR - São Paulo: Comitê Gestor da Internet no Brasil, 2018. Disponível em:

https://www.cgi.br/media/docs/publicacoes/2/tic_dom_2017_livro_eletronico.pdf. Acesso em: 25 jan. 2021.

CGI.br - Comitê Gestor da Internet no Brasil. TIC Domicílios 2018: Pesquisa Sobre o Uso das Tecnologias de Informação e Comunicação nos Domicílios Brasileiros. Núcleo de Informação e Coordenação do Ponto BR - São Paulo: Comitê Gestor da Internet no Brasil, 2019. Disponível em: https://cetic.br/media/docs/publicacoes/2/12225320191028tic_dom_2018_livro_eletronico.pdf. Acesso em: 24 jan. 2021.

CGI.br - Comitê Gestor da Internet no Brasil. TIC Domicílios 2019: Pesquisa Sobre o Uso das Tecnologias de Informação e Comunicação nos Domicílios Brasileiros. Núcleo de Informação e Coordenação do Ponto BR - São Paulo: Comitê Gestor da Internet no Brasil, 2020. Disponível em:

https://www.cetic.br/media/docs/publicacoes/2/20201123121817/tic_dom_2019_livro_ele tronico.pdf. Acesso em: 24 jan. 2021.

CGI.br - Comitê Gestor da Internet no Brasil. TIC Kids Online Brasil 2o2o: Pesquisa 
sobre o Uso da Internet por Crianças e Adolescentes no Brasil. Núcleo de Informação e Coordenação do Ponto BR - São Paulo: Comitê Gestor da Internet no Brasil, 2021. Disponível em: https://cetic.br/pt/publicacao/pesquisa-sobre-o-uso-da-internet-por-criancas-eadolescentes-no-brasil-tic-kids-online-brasil-2020/. Acesso em: 05 jan. 2022.

CLAREMONT, B. A beginner's guide to tiny planet photography. 3. ed. [S. l.: s. n.], 2019.

FALANDES, C. G.; ANGELUCI, A. C. B. A Imagem Digital em Perspectiva: Percepções sobre a Linguagem $360^{\circ}$ no Cotidiano dos Jovens. In: GORDILLO, I.; BARCELOS, J.; BRESSAN, D.; ROSSI, D. (org.). Perspectivas imagéticas. $1^{\text {a }}$ edição. Aveiro: Ria Editorial, 2019, pp. 207-234.a

FALANDES, C. G.; ANGELUCI, A. C. B. Produção de uma narrativa complexa: as estratégias utilizadas no webdocumentário Jovens e as Imagens - Relatos e Experiências em 360 Graus. Contracampo (UFF), v. 39, n. 3, p. 1-20, 2020.

FALANDES, C. G.; ANGELUCI, A. C. B. Usos e apropriações da imagem em 360 graus no Instagram. In: CAPRINO, M. P.; PERAZZO, P. F. (org.). Comunicação e cultura: aproximações com memória e história oral - Diálogos entre Brasil e México. Anais do III Simpósio Internacional. São Caetano do Sul: USCS, 2019, pp. 722-739.b

FEIXA, C. Generación @ - la juventud en la era digital. Nómadas, n. 13, p. 75-91, 2000. Disponível em: https://repositori.udl.cat/handle/10459.1/56715. Acesso em: 20 ago. 2021.

FONTCUBERTA, J. La furia de las imágenes: notas sobre la postfotografía. Barcelona: Galaxia Gutenberg, 2016.

FUNDAÇÃO TELEFÔNICA. Juventude Conectada. São Paulo: Fundação Telefônica, 2014. 200 p. Disponível em: http://fundacaotelefonicavivo.org.br/wp-

content/uploads/pdfs/juventude_conectada-online.pdf. Acesso em: 05 jan. 2022.

GIL, A. C. Como elaborar projetos de pesquisa. 5a ed. São Paulo: Editora Atlas S. A, 2010.

IBGE - Instituto Brasileiro de Geografia e Estatística. Pesquisa Nacional por Amostra de Domicílios Contínua - PNAD Contínua. Acesso à Internet e à televisão e posse de telefone móvel celular para uso pessoal 2018 - Informativo. Coordenação de Trabalho e Rendimento. Rio de Janeiro: IBGE, 2020. Disponível em:

https://biblioteca.ibge.gov.br/index.php/biblioteca-catalogo?view=detalhes\&id=2101705. Acesso em: 24 jan. 2021.

KERCHOVE, D. Ética de transparência na era do Big Data. In: LOPES, M. I. V.; KUNSCH, M. K. (org.). Comunicação, cultura e mídias sociais. São Paulo: ECA-USP, 2015, pp. 1-13. Disponível em: http://www.assibercom.org/arquivos/o2_congresso_ibercom_2015.pdf. Acesso em: 30 nov. 2020.

LONGHI, R. Jornalismo imersivo e narrativas complexas. Videoconferência publicada pelo canal MEISTUDIES - Media Ecology and Image Studies (vídeo: 25 min e 20 seg.). 26 set. 2019. Disponível em: https://youtu.be/puu8vwyoc_U. Acesso em: 26 jan. 2020.

MANOVICH, L. Software takes command. New York: Bloomsbury Academic, 2013.

MEDEIROS, R. F. Os adolescentes e os aparelhos celulares: visualidades contemporâneas. 2018. 203 f. Tese (Doutorado em Educação) - Programa de Pós-Graduação em Educação, Universidade Federal do Rio Grande do Sul, Porto Alegre, 2018. Disponível 
em:

https://lume.ufrgs.br/bitstream/handle/10183/183145/o01078557.pdf?sequence=1\&isAllow ed=y. Acesso em: 17 dez. 2019.

ORO, P. Los jóvenes y la fotografía: su rol dentro del nuevo ecosistema de medios y en la era de los prosumidores. In: Memórias - $1^{\circ}$ Congresso Internacional Media Ecology and Image Studies. Portugal: Ria Editorial, out. 2018, pp. 371-382. Disponível em: http://docs.wixstatic.com/ugd/43846c_9628362b9c4d4c938d2afe5de6a205c8.pdf. Acesso em: 25 jan. 2021.

PASSARELLI, B. Jovens brasileiros em conectividade contínua: estudos e tendências. Revista Juventude e Políticas Públicas, Brasília, v. 1, Edição Especial, p. 1-16, fev. 2020. Disponível em: https://revistasnj.mdh.gov.br/index.php/snj/article/view/125/98. Acesso em: 01 maio. 2021.

PASSARELLI, B.; JUNQUEIRA, A. H.; ANGELUCI, A. C. B. Os nativos digitais no Brasil e seus comportamentos diante das telas. Matrizes, v. 8, n. 1, p. 159-178, 2014. Disponível em: https://www.revistas.usp.br/matrizes/article/view/82936. Acesso em: 25 jan. 2021.

PNUD - Programa das Nações Unidas para o Desenvolvimento. Índice de

Desenvolvimento Humano Municipal Brasileiro. Atlas do Desenvolvimento Humano no Brasil 2013. Brasília: PNUD, Ipea, FJP, 2013. Disponível em:

https://www.ipea.gov.br/portal/index.php?option=com_content\&id=19153. Acesso em: 25 jan. 2021.

POMPEU, B.; SATO, S. K. Juventude, tecnologia e inovação: uma construção mítica na Contemporaneidade. Mídia e Cotidiano, v. 11, n. 3, p. 41-56, dez. 2017. Disponível em: https://periodicos.uff.br/midiaecotidiano/article/view/9844. Acesso em: 25 jan. 2021.

PRENSKY, M. Digital natives, digital immigrants. On the Horizon, v. 9, n. 5, p. 1-6, 2001.

RANKING CONNECTED SMART CITIES. Edição 2020 - São Caetano do Sul. São Paulo: Urban Systems, 2020. Disponível em:

https://ranking.connectedsmartcities.com.br/resultados-cidade.php. Acesso em: 02 maio. 2021.

RECUERO, R. Redes sociais na internet, difusão de informação e jornalismo: elementos para discussão. In: SOSTER, D. A.; FIRMINO, F. (org.). Metamorfoses jornalísticas 2: a reconfiguração da forma. Santa Cruz do Sul: UNISC, 2009, pp. 1-269.

SANTAELLA, L. A cultura digital na berlinda. In: LOPES, M. I. V.; KUNSCH, M. K. (org.). Comunicação, cultura e mídias sociais. São Paulo: ECA-USP, 2015, pp. 93-101. Disponível em: http://www.assibercom.org/arquivos/o2_congresso_ibercom_2015.pdf. Acesso em: 30 nov. 2020.

SATLER, L. L.; CARRIJO, A. J. F. O que adolescentes pensam sobre o compartilhamento de si na internet? Mídia e Cotidiano, v. 15, n. 1, p. 111-130, jan./abr. 2021. Disponível em: https://periodicos.uff.br/midiaecotidiano/article/view/43146/27989. Acesso em: 25 jan. 2021.

SAWYER, S. M.; AZZOPARDI, P. S.; WICKREMARATHNE, D.; PATTON, G. C. The age of adolescence. The Lancet Child \& Adolescent Health, v. 2, n. 3, pp. 223-228, mar. 2018.

STRAUSS, W.; HOWE, N. Generations: the history of America's Future, 1584 to 2069. New York: William Morrow and Company Inc., 1991. 
SCOLARI, C. A. A comunicação móvel está no centro dos processos de convergência cultural contemporâneos. Intercom - Revista Brasileira de Ciências da

Comunicação, São Paulo, v. 39, n. 2, p. 177-184, mai./ago. 2016. Disponível em: https://www.scielo.br/scielo.php?script=sci_arttext\&pid=S1809-58442016000200177. Acesso em: 02 mai. 2021.

SCOLARI, C. A. Tweetland: nuevos formatos textuales en la cultura snack. Observatorio de Cultura y Economía. República de Colombia. Bogotá: D. C., 2019. Disponível em: https://culturayeconomia.org/wp-content/uploads/Carlos-Scolari-final.pdf. Acesso em: 03 mai. 2021.

TAPSCOTT, D. Growing Up Digital: The Rise of the Net Generation. New York: McGraw Hill, 1998.

TOFFLER, A. A terceira onda. 17.ed. Rio de Janeiro: Record, 1980.

UNICEF - United Nations Children's Fund. The state of the world's children 2017 Children in a Digital World. New York: UNICEF, dez. 2017. Disponível em: https://www.unicef.org/publications/files/SOWC_2017_ENG_WEB.pdf. Acesso em: 25 jan. 2021.

Este é um ARTIGO publicado em acesso aberto (Open Access) sob a licença Creative Commons Attribution, que permite uso, distribuição e reprodução em qualquer meio, sem restrições, desde que o trabalho original seja corretamente citado. 